\title{
Physico-Chemical Assessment of Drinking Water Available to the Inhabitants of Low Income and Thickly Populated Areas of Karachi City
}

\author{
Syeda Tehniat Sakina Naqvi \\ Graduate School (FEST), Hamdard University, Karachi, Pakistan \\ Abdul Hameed Memon \\ Mechanical Engineering Department (FEST), Hamdard University, Karachi, Pakistan \\ Muhammad Usama Zafar, \\ Graduate School (FEST), Hamdard University, Karachi, Pakistan \\ Muhammad Tariq Hussain \\ Graduate School (FEST), Hamdard University, Karachi, Pakistan \\ Ibrahim Jaffery \\ Pakistan standard and quality control authority (PSQCA)
}

\begin{abstract}
The aim of this study was to investigate the physico-chemical properties of drinking water available to the population of low income areas of Karachi city. The study incorporated the attention towards the fluoride content in water being used for domestic and drinking purpose by the inhabitants of low income and thickly populated areas of Karachi. Samples were collected from selected locations from all the districts of Karachi city. Laboratory tests were performed to analyze both physical and chemical characteristics of drinking water. It was observed in this study that except few of the locations, fluoride content was present either in low concentration or in high concentration. Medical data of the areas under study was collected through questionnaires and survey forms. The consequence of the variation of fluoride concentration was found to be in agreement with the findings of medical data analyzed from concerned areas where both cases of Fluorosis and dental cavities were reported. Correlation of fluoride with other parameters was analyzed using principle component analysis determined PC1 \& PC2 as most significant components. PC1 showed dominance of TDS with salts while PC2 indicated loadings were temperature DO \& pH. Monitoring of fluoride ion concentration and other health related parameters are essential for the development of efficient water management system. Fluoride content in drinking water should be regulated by periodic assessment and elevated levels can be controlled by adsorption or membrane techniques.

Keywords: Physico-chemical properties, drinking water, districts of Karachi, fluoride variation, correlation analysis, principle component analysis, water management system.

DOI: $10.7176 / \mathrm{JNSR} / 11-14-01$

Publication date:July $31^{\text {st }} 2020$

\section{INTRODUCTION}

Water is a vital factor to sustain life and to achieve equitable economic growth for a country. As the population is increasing the water supply system is getting pressure instead of keeping pace and water related facilities are getting compromised [1]. Availability of fresh water is limited and requires proper management to meet the basic requirement. Continuous industrialization is one of major consequence in the reduction of availability of safe drinking water. Pakistan is among those states which are facing with water deficit and might get deadly shortage of safe water till the end of 2025 [2]. The availability of water in Pakistan has declined from 5000m3 per annum in 1951 to 1100 which is more than the internationally recognized rate of scarcity. Also it was observed that $40 \%$ of the diseases are water borne in Pakistan [3]. Population migration and industrialization are found as the root cause of water quality deterioration in various big cities like Lahore, Islamabad, Faisalabad, Rawalpindi, Qasur and especially in Karachi [4]. Water becomes also contaminated by lack of maintenance of supply system through input of sewage [5]. Ground water fluoride originated largely from naturally reserved mineral salts (fluorite, apatite, topaz, micas and amphibole). The amount of chemical constituents present in water is related to its source and stimulated by domestic and industrial activities [6]. Inorganic elements are associated with health and aesthetics especially fluoride and arsenic [7]. Mineral salts present naturally in water acts as a dental carriespreventive agent. Fluoride is one of the top ten mineral salts pertinent to human health [8].

It is observed that fluoride enters in freshwater bodies through precipitation, soil leaching, and some industrial activities [9]. However food, drinking water and rocks are considered as major sources of fluoride. Earth crust
\end{abstract}


consists of approximately 85 million tons of fluoride naturally (UNICEF 1999). Fluoride helps in the process of remineralization and prevents tooth decay. It plays a significant role in the formation of strong teeth enamel. Fluoride within the concentration range of $0.5-1.0 \mathrm{ppm}$ in water is beneficial for dental and skeletal health [10]. Although recommended value of fluoride by WHO ranges $0.5-1.5 \mathrm{ppm}$ but many countries considered $1.5 \mathrm{ppm}$ as maximum contaminent level [11]. 75\% fluoride enters in our body via drinking water source. Its deficiency and exceedance can cause serious health issues such as elevated fluoride level is responsible for dental disease and fluorosis. Some other diseases are also associated with fluoride content in the body including osteoporosis, decreased blood cell count, genetic impairment (chromosomal aberrations) and mental retardation [12]. It was identified in a study that in mammalian cells extreme high concentration of fluoride may responsible of genetic disorder [13]. Repeated exposure of fluoride ion may affect body tissues specifically brain related activities [14]. Studies on this aspect proved that elevated levels of fluoride in water results in the rise of fluoride content of enamel [15]. The prevalence of fluoride toxicity globally is generating negative impacts on the population of both developed and under developed states.

U.S. researcher investigated the incidence of Osteosarcoma and fluoride toxicity. His findings revealed the relationship of fluoride with Osteosarcoma in males and children [16]. However a study conducted by Wang et al. from China disclosed drinking water fluoride association with neurological impacts on children [17]. Fluoride identification is now became an essential characteristic to evaluate dental disease commonly dental Fluorosis and dental carries [18]. Fluoride produces direct impact on human health which is indirectly associated with social, economical and environmental needs. Therefore progressive deterioration in water quality consequently conceives economic distress and social adversity. As sustainable development in any community is a key factor to take initiative for an improved standard of living for the populace [19], that's why to acknowledge the sustainable use and management of natural resources current study has been conducted to monitor water quality system, spatial distribution of fluoride ion and its related impacts on human health. It is suggested that certain training \& awareness sessions, smart technologies and research facilities are required on management level for the improvement of water quality and its related services. Furthermore as the fluoride based solutions are concerned, it is recommended that fluoride supplements should be a part of water supply system where fluoride is in low concentration and in course of high fluoride content in drinking water membrane techniques reverse osmosis, nano filtration, electrodialysis and adsorption methods like alumina or carbon materials can be adopted. The main supply of water to Karachi city is provided from Indus river and affiliated lakes included Keenjhar and Hub river canal. In Karachi due to the scarcity of supply water and expense of bottled water people from certain districts are switching toward underground water [20]. Substantial withdrawal of groundwater is also an aspect in the detriment of water quality resulting salt water intrusion [21]. This study critically point out the fluoride distribution among different districts of Karachi city to improve population health as well as to create attention note for future betterment.

\section{METHODOLOGY}

Study Area

Karachi is situated on a coastal plain comprised of rocky outcroppings, hills and coastal marshlands having shaleclay and lime stones. The current population of Karachi is 16 million as per census of 2017. It is a dense city having area of $3780 \mathrm{~km}^{2}$ and located at latitude 24 degree $50 \mathrm{~min}$ North to 25 degree $30 \mathrm{~min}$ North while longitudes 66 degree 55 min East to 67 degree 55 min East in Sindh.

In order to get representative data for analysis of water quality available to the people research was focused to collect water samples from selected areas. The area of study was carried out covering high density residential, commercial and industrial areas of Karachi city by considering its districts. Karachi is divided into six districts which further sub categorized into several regions. The representative samples of surface, ground and bottled water were collected from highly populated areas of Karachi. Total twelve areas were selected from different districts for sampling as shown in Table 1. The geographical locations of the areas were determined with help of GIS as shown in (Fig 1).

Table 1: Districts and selected areas of Karachi

\begin{tabular}{|l|l|}
\hline Districts & Sub regions \\
\hline Karachi Central & New Karachi North Nazimabad \\
\hline Karachi East & Shara-e-faisal Gulzar-e-hijri \\
\hline Karachi West & Garden Lyari \\
\hline Karachi South & $\begin{array}{l}\text { Baldia } \\
\text { Mominabad }\end{array}$ \\
\hline Malir District & Murad Memon Ibrahim Hyderi \\
\hline Korangi District & Korangi \\
& Landhi \\
\hline
\end{tabular}




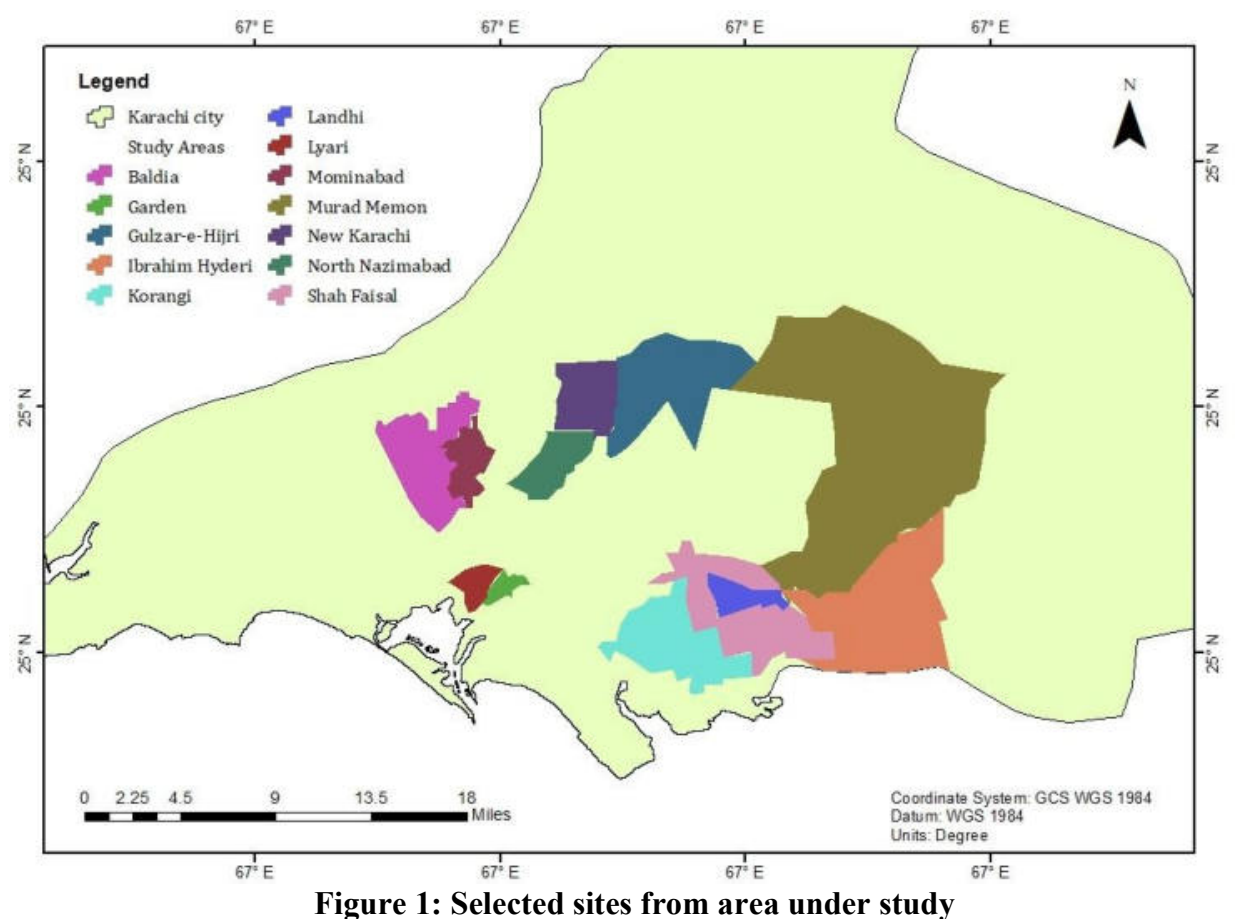

\section{Water Sample Analysis}

In all 60 water samples were collected which included thirty one samples from supply water nineteen samples from ground water and ten samples from bottled water. Samples were collected in water bottles of 500ml volume. Water samples were analyzed for physical parameters $\mathrm{pH}$, temperature, total dissolved solids (TDS) and chemical analysis include dissolved oxygen (DO), fluoride $\left(\mathrm{F}^{-}\right)$, chloride $\left(\mathrm{Cl}^{-}\right)$, calcium $\left(\mathrm{Ca}^{2+}\right)$, magnesium $\left(\mathrm{Mg}^{2+}\right)$, sodium $\left(\mathrm{Na}^{+}\right)$, potassium $\left(\mathrm{K}^{+}\right)$by standard methods of APHA (2001) . In brief TDS and DO were analyzed by using TDS meter and DO meter. Fluoride is detected by using spectrophotometer technique. Sodium, potassium by flame photometry while calcium, magnesium and chloride were analyzed by titrimetry method. Statistical analyses were performed indicating mean $\pm \mathrm{SD}$ and median. Correlation analyses focusing principle component analyses. GIS (Geographical Information System) used for the identification of fluoride variation spatially.

\section{Medical Data Collection}

The purpose of this research was also to find the consequential impact of water quality on the residents of the area. Therefore detailed medical survey of the selected area was also conducted to collect medical complaints of the people. Data was collected from 96 families where each family comprised of five to six members. Collectively all 505 people were interviewed.

\section{RESULTS AND DISCUSSIONS}

The findings of Karachi medical survey from different hospitals/ clinics \& public interviews indicated high rate of dental disease in most of the areas under study. The rate of dental disease is elucidated by bar graphical presentation (Fig 2). According to the data the most critical areas under study in terms of dental illness are Murad Memon, Landhi and Sharah-e-Faisal. After experimental study of these areas Landhi and Sharah-e-Faisal proved with low level of fluoride which may justify the ratio of dental diseases found during the survey. Dental diseases observed in abundance were dental carries, cavities and weakness of teeth described in Table 2. The results of tap, ground and bottled water are tabulated in Table $3 \& 4$. 


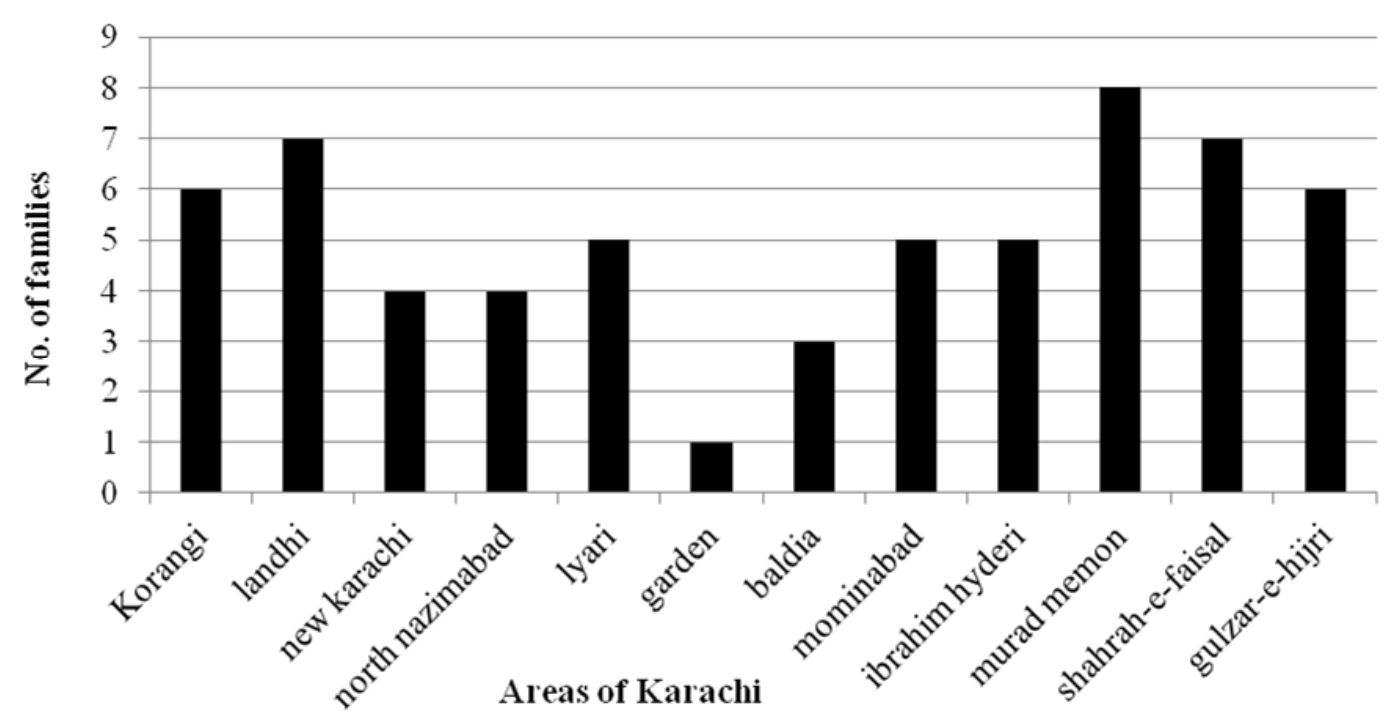

Figure 2: Frequency of dental Disease

Table 2: Health risk reported in districts of Karachi

\begin{tabular}{|c|l|}
\hline District & Health implication \\
\hline Central & Dental carries, cavities \\
\hline East & Dental carries, cavities, weakness \\
\hline South & Weakness, cavities, discolouration \\
\hline West & Weakness, Fluorosis cavities, irregularity \\
\hline Korangi & Cavities, Fluorosis and dental gaps \\
\hline Malir & Weakness dental carries and cavities \\
\hline
\end{tabular}

The quality of water depends on various parameters used to indicate the levels of contamination. Each parameter is compared with WHO set standards. The factors involved in the variation of fluoride and other parameters have also been discussed. Temperature observed was in range 23-30. Certain industrial effluents and density of streams can influence on water temperature [6] which might be also the case of current study.

Table 3: Results of tap and ground water samples

\begin{tabular}{|c|c|c|c|c|c|c|c|c|c|c|c|c|c|}
\hline SNo & Location & Type of sample & $\mathrm{pH}$ & $\begin{array}{l}\text { TDS } \\
\text { ppm }\end{array}$ & $\begin{array}{l}\text { DO } \\
\text { ppm }\end{array}$ & $\begin{array}{l}\text { Temp } \\
{ }^{\circ} \mathrm{C}\end{array}$ & $\begin{array}{l}\text { Ca } \\
\text { ppm }\end{array}$ & $\begin{array}{l}\text { Mg } \\
\text { ppm }\end{array}$ & $\begin{array}{l}\mathrm{Q} \\
\mathrm{ppm}\end{array}$ & $\begin{array}{l}\text { F } \\
\text { ppm }\end{array}$ & $\begin{array}{l}\mathrm{Na} \\
\text { ppm }\end{array}$ & $\begin{array}{l}\text { K } \\
\text { ppm }\end{array}$ & Diseases \\
\hline 1 & Korangi & Tapwater & 7.7 & 258 & 6.97 & 35 & 24 & 34 & 277 & 0.02 & 58 & 8 & Dentalcavities \\
\hline 2 & Korangi & Tapwater & 7.8 & 251 & 7.82 & 35.4 & 36 & 7 & 106 & 1.7 & 15 & 15 & Dental Fluorosis \\
\hline 3 & Korangi & Ground water & 8.5 & 304 & 73 & 34.9 & 32 & 63 & 418 & 09 & 143 & 9 & Dentalcavities \\
\hline 4 & Korangi & Ground water & 8.3 & 443 & 6.46 & 34.7 & 180 & 204 & 2304 & 0 & 287 & 11 & Dentalcavities \\
\hline 5 & Landhi & Tapwater & 8.5 & 251 & 737 & 34 & 32 & 46 & 170 & 02 & 57 & 8 & Otherthandental \\
\hline 6 & Landhi & ROwater & 8 & 255 & 7.15 & 35 & 32 & 32 & 135 & 03 & 60 & 8 & Otherthandental \\
\hline 7 & Landhi & Groundwater & 8 & 301 & 7.02 & 362 & 136 & 34 & 354 & 0.6 & 123 & 17 & Gapsinteeth \\
\hline 8 & Landhi & Groundwater & 8.5 & 255 & 6.54 & 36.8 & 40 & 24 & 177 & 03 & 63 & 6 & Otherthan dental \\
\hline 9 & Gulzar-e-Hiji & Tapwater & 8.5 & 247 & 6.85 & 35.5 & 28 & 32 & 106 & 03 & 30 & 4 & Inegulartecth \\
\hline 10 & Gukar-e-Hiji & Tapwater & 8.5 & 252 & 7.76 & 34.7 & 60 & 22 & 177 & 03 & 60 & 7 & Otherthandental \\
\hline 11 & Gulzar-e-Hiji & Tapwater & 8.4 & 302 & 726 & 34.2 & 32 & 22 & 170 & 03 & 53 & 6 & Dental weakness \\
\hline 12 & Gulzar-e-Hijii & Tapwater & 8.6 & 256 & 7.03 & 34.6 & 32 & 15 & 135 & 03 & 57 & 8 & Dentalcavities \\
\hline 13 & Lyari & Tapwater & 11 & 301 & 731 & 32 & 68 & 12 & 177 & 04 & 67 & 6 & Dentalcavities \\
\hline 14 & Lyari & Groundwater & 12 & 413 & 83 & 32.1 & 56 & 47 & 486 & 12 & 245 & 42 & Dental weakness \\
\hline 15 & Lyari & Groundwater & 11 & 250 & 835 & 32.4 & 52 & 17 & 142 & 02 & 55 & 6 & Dental camies \\
\hline 16 & Lyair & Tapwater & 10.5 & 467 & 626 & 33.5 & 84 & 70 & 213 & 1.6 & 83 & 16 & Dentallfuorosis \\
\hline 17 & Lyari & Ground water & 10.5 & 259 & 7.03 & 332 & 44 & 22 & 170 & 0.1 & 67 & 9 & Dental weakness \\
\hline 18 & Mominabad & Tapwater & 11 & 234 & 7.84 & 32.4 & 28 & 15 & 71 & 03 & 37 & 4 & Dental cavities \\
\hline 19 & Mominabad & Groundwater & 11 & 487 & 7.45 & 32.4 & 108 & 112 & 1134 & 1.6 & 230 & 9 & Dentalcavities \\
\hline 20 & Mominabad & Tapwater & 11.5 & 258 & 7.8 & 31.6 & 44 & 7 & 142 & 05 & 45 & 6 & Imegulartech \\
\hline 21 & Mominabad & Tapwater & 11 & 265 & 833 & 31.9 & 80 & 5 & 106 & 02 & 47 & 4 & gapsinteeth \\
\hline 22 & Baldia & Tapwater & 10.8 & 278 & 72 & 31.7 & 40 & 27 & 177 & 05 & 45 & 4 & Discolouration \& gaps \\
\hline 23 & Baldia & Groundwater & 10 & 245 & 735 & 32.6 & 48 & 34 & 177 & 1.1 & 30 & 3 & Discolouration \\
\hline
\end{tabular}




\begin{tabular}{|c|c|c|c|c|c|c|c|c|c|c|c|c|c|}
\hline SNo & Location & Typeofsample & $\mathrm{pH}$ & $\begin{array}{l}\text { TDS } \\
\text { ppm }\end{array}$ & $\begin{array}{l}\text { DO } \\
\text { ppm }\end{array}$ & $\begin{array}{l}\text { Temp } \\
{ }^{\circ} \mathrm{C} \\
\end{array}$ & $\begin{array}{l}\text { Ca } \\
\text { ppm }\end{array}$ & $\begin{array}{l}\text { Mg } \\
\text { ppm }\end{array}$ & $\begin{array}{l}\mathrm{C} \\
\mathrm{ppm}\end{array}$ & $\begin{array}{l}\text { F } \\
\text { ppm }\end{array}$ & $\begin{array}{l}\text { Na } \\
\text { ppm }\end{array}$ & $\begin{array}{l}\text { K } \\
\text { ppm }\end{array}$ & Diseases \\
\hline 24 & Baldia & Tapwater & 112 & 249 & 7.71 & 32.1 & 84 & 10 & 106 & 0.5 & 45 & 4 & Dentalcavities \\
\hline 25 & Baldia & Tapwater & 12 & 242 & 7.63 & 31.1 & 56 & 2 & 106 & 0.6 & 45 & 4 & Dental weakness \\
\hline 26 & NorthNazimabad & Tapwater & 11 & 254 & 8.01 & 31.9 & 44 & 19 & 177 & 0.6 & 65 & 4 & Dental Cavities\&Camies \\
\hline 27 & NorthNazimabad & Ground water & 9 & 262 & 7.74 & 32 & 84 & 29 & 319 & 0.6 & 115 & 8 & OtherThanDental \\
\hline 28 & NorthNazimabad & ROwater & 8 & 243 & 7.63 & 31.7 & 28 & 7 & 71 & 0.04 & 36 & 5 & DentalCavities\&Camies \\
\hline 29 & NorthNazimabad & Tapwater & 9 & 252 & 799 & 31.5 & 44 & 34 & 170 & 0.6 & 67 & 6 & OtherThanDental \\
\hline 30 & NewKarachi & Tapwater & 8.5 & 234 & 756 & 31.2 & 36 & 22 & 142 & 0.6 & 65 & 6 & DentalCavities\&Camie \\
\hline 31 & NewKarachi & Tapwater & 7.5 & 248 & 8.7 & 29 & 52 & 24 & 142 & 02 & 57 & 5 & Discolouration \\
\hline 32 & NewKarachi & Tapwater & 8 & 255 & 8.07 & 327 & 60 & 12 & 17 & 0.6 & 65 & 6 & DentalCavities \\
\hline 33 & NewKarachi & Groundwater & 7.5 & 485 & 70.6 & 30.3 & 44 & 284 & 1064 & 1 & 265 & 16 & ReportedNoIssue \\
\hline 34 & Garden & Tapwater & 7 & 238 & 924 & 34 & 48 & 63 & 390 & 0.1 & 150 & 6 & ReportedNoIssue \\
\hline 35 & Garden & Tapwater & 7.2 & 224 & 92 & 34.6 & 36 & 22 & 106 & 02 & 50 & 3 & ReportedNoIssue \\
\hline 36 & Garden & $\mathrm{T}$ & 7 & 247 & 9.16 & 34 & 52 & 22 & 177 & 0.4 & 65 & 4 & DentalWeakness \\
\hline 37 & Garden & Tapwater & 7.5 & 219 & 931 & 34.2 & 28 & 56 & 248 & 02 & 110 & 4 & tion \\
\hline 38 & IbrahimHydari & Tapwater & 8 & 232 & 959 & 34.2 & 28 & 39 & 135 & 02 & 53 & 4 & DentalWeakness \\
\hline 39 & IbrahimHyderi & Tapwater & 7 & 239 & 9.65 & 34.2 & 40 & 39 & 142 & 02 & 45 & 6 & ReportedNo Issue \\
\hline 40 & IbrahimHyderi & Tapwater & 7 & 240 & 9.65 & 34.2 & 52 & 22 & 177 & 02 & 60 & 4 & ReportedNolssue \\
\hline 41 & IbrahimHyderi & Tapwater & 8 & 254 & 9.76 & 35.5 & 52 & 19 & 248 & 02 & 67 & 4 & RepotedNolssue \\
\hline 42 & MuradMemon & Groul & 8 & 256 & 799 & 34 & 60 & 83 & 354 & 0.8 & 95 & 8 & DentalCaries\&Cavities \\
\hline 43 & MuradMemon & Groundwater & 7.5 & 248 & 925 & 34.2 & 56 & 39 & 142 & 0.6 & 30 & 4 & Dental Cavities \\
\hline 44 & $\begin{array}{l}\text { Murad } \\
\text { Memon }\end{array}$ & iter & 7.5 & 256 & 992 & 34 & 80 & 80 & 354 & 0.9 & 125 & 9 & Discolouration \\
\hline 45 & $\begin{array}{l}\text { Murad } \\
\text { Memon }\end{array}$ & Tapwater & 8 & 257 & 9.4 & 34.2 & 64 & 80 & 248 & 0.7 & 80 & 6 & Dental Caries \\
\hline 46 & Shara-Faisal & ROwater & 7 & 249 & 14.06 & 34 & 40 & 2 & 99 & 0.1 & 30 & 1.5 & DentalCaries \\
\hline 47 & Sharae-Faisal & Ground water & 7 & 238 & 125 & 34 & 28 & 5 & 99 & 0 & 37 & 1.5 & DentalWeakness \\
\hline 48 & Sharae-Faisal & Tapwater & 7 & 256 & 835 & 35 & 40 & 24 & 135 & 0.7 & 60 & 4 & Weakness\& Inegulanity \\
\hline 49 & Sharae-Faisal & Ground water & 7 & 254 & 9.4 & 35 & 44 & 2 & 99 & 0.05 & 37 & 1.5 & DentalCavities \\
\hline 50 & Shahrae-Faisal & Tapwater & 7.5 & 255 & 7.1 & 35 & 16 & 51 & 99 & 0.1 & 17 & 1.5 & DentalSpots \\
\hline
\end{tabular}

In current study $\mathrm{pH}$ range observed is neutral to alkaline (7-12). Alkaline $\mathrm{pH}$ may be due to presence of rock formations which results more carbonates and bicarbonates. Above to $8.5 \mathrm{pH}$ considered as alkaline and determined by bitter taste and scaling effect. TDS in water is a vital factor accountable for saline behavior of water. TDS found in different districts of Karachi ranges 219-487 ppm which is considered under the WHO prescribed limits but variation occurred which might be due to some human induced sources of minerals that are accountable for increased or variate TDS values like use of fertilizers and industrial discharge. Calcium and magnesium are essential ions for human body and create water hardness. In present study there is high variation observed in calcium and magnesium concentrations.

Naturally water has a definite amount of calcium and magnesium ion but it may disturb due to leakages and constructional activities. High calcium ion may present because of dolomite and calcite formation of that areas [22].

Permissible sodium concentration recommended by WHO is $220 \mathrm{ppm}$ while observed range in study is 5-287 ppm which is acceptable except few of the samples showed high Na. It is reported by WHO that some of the chemicals utilized for water treatment processes e.g. sodium hydroxide, sodium silico fluoride, sodium fluoride, sodium carbonate, sodium bicarbonate and sodium hypochlorite can add $\mathrm{Na}$ ion in drinking water (PCRWR, 2007).

Potassium range investigated between 0-17 ppm and is suitable for drinking but one sample of ground water from Lyari showed $42 \mathrm{ppm}$ potassium which is high as compared to other water samples. Source of potassium in drinking water can be the use of potassium permanganate as oxidant in water treatment (WHO). Out of all parameters studied WHO has not defined any limit for potassium and dissolved oxygen concentrations. D.O should not below to $4 \mathrm{ppm}$ recommended by some scientists [6]. Potassium and D.O values have observed above to 4 ppm in present study. According to the results presented in Table $3 \& 4$, one tap water sample collected from Korangi and other one from Lyari showed elevated level of fluoride prescribed by WHO. The conditions of drinking water in Lyari found unsatisfactory when surveyed. The reason may be industries present in Korangi area or concentrated amount of fluoride can associate with the presence of rocks present in South and Korangi district of Karachi. Water which passes from mineral rich rocks can carry fluoride salts which are supplied to people in drinking water $[23,24]$. Additionally one ground water sample of Mominabad also resulted high fluoride content. Elevated levels of salts in subsurface water might be due to geological location. In earlier studies it is stated that ground water become contaminated with salts on the basis of geology of certain area [25]. Presence of Scheelite structures which consists of coal layers and Alluvial deposits can create high concentrations of fluoride in ground 
waters [8]. In current study spatial distribution of Fluoride was identified as shown in Fig 3 \& 4. Samples which have crossed the permissible limits of fluoride by WHO standards also have high concentrations of other analyzed ions. Ten samples of most commonly available bottled water products in Karachi city were analyzed given in Table 4. Findings presented all the drinking water parameters tested for bottled water samples were within recommended values of WHO. Mean, median and standard deviation was calculated of all samples as shown below in Table 5 and their correlation was studied in Table $6 \& 7$.

Table 4: Results of bottled water of Karachi

\begin{tabular}{|c|c|c|c|c|c|c|c|c|c|c|c|c|}
\hline S.No & Location & Type of sample & $\mathrm{pH}$ & $\begin{array}{c}\text { TDS } \\
\text { ppm }\end{array}$ & $\begin{array}{l}\text { DO } \\
\text { ppm }\end{array}$ & $\begin{array}{l}\text { Temp } \\
{ }^{\circ} \mathrm{C}\end{array}$ & $\begin{array}{l}\mathrm{Ca} \\
\mathrm{ppm}\end{array}$ & $\begin{array}{l}\text { Mg } \\
\text { ppm }\end{array}$ & $\begin{array}{l}\mathrm{Cl} \\
\mathrm{ppm}\end{array}$ & $\begin{array}{l}\text { F } \\
\text { ppm }\end{array}$ & $\begin{array}{l}\mathrm{Na} \\
\mathrm{ppm}\end{array}$ & $\begin{array}{c}\mathrm{K} \\
\mathbf{p p m}\end{array}$ \\
\hline
\end{tabular}

\begin{tabular}{|r|r|l|r|r|r|r|r|r|r|r|r|r|}
\hline 51 & A & Bottled water & 7 & 253 & 9.6 & 23 & 32 & 29 & 106 & 0.1 & 35 & 1 \\
\hline 52 & B & Bottled water & 7 & 255 & 9.87 & 24 & 64 & 2 & 177 & 0.1 & 15 & 1 \\
\hline 53 & $\mathrm{C}$ & Bottled water & 7.2 & 250 & 11.87 & 23 & 48 & 41 & 142 & 0.1 & 30 & 4 \\
\hline 54 & $\mathrm{D}$ & Bottled water & 8 & 254 & 13.42 & 23 & 32 & 10 & 35 & 0.05 & 10 & 1.5 \\
\hline 55 & $\mathrm{E}$ & Bottled water & 7 & 252 & 8.23 & 24 & 20 & 27 & 71 & 0.2 & 20 & 1.5 \\
\hline 56 & $\mathrm{~F}$ & Bottled water & 7.2 & 255 & 13.11 & 24 & 48 & 5 & 99 & 0.3 & 10 & 1.5 \\
\hline 57 & $\mathrm{G}$ & Bottled water & 7 & 251 & 11.57 & 24 & 24 & 29 & 142 & 0.08 & 30 & 1 \\
\hline 58 & $\mathrm{H}$ & Bottled water & 7 & 250 & 12.59 & 24 & 40 & 24 & 106 & 0.2 & 5 & 4 \\
\hline 59 & $\mathrm{I}$ & Bottled water & 7.5 & 254 & 12.45 & 24 & 40 & 2 & 135 & 0.5 & 27 & 1.5 \\
\hline 60 & $\mathrm{~J}$ & Bottled water & 7 & 256 & 11.3 & 24 & 48 & 12 & 71 & 0.1 & 20 & 0 \\
\hline
\end{tabular}

Note: Bottle water samples were collected from most consumable company products of Karachi city.

By keeping their names confidential number of samples denoted in the above table as A, B, C.... J.

Table 5: Statistical analysis of water samples of Karachi

\begin{tabular}{|l|ll|l|l|l|}
\hline Variable & Mean & \pm St. Dev & Minimum & Median & Maximum \\
\hline $\mathrm{p} \mathrm{H}$ & 8.473 & 1.548 & 7.000 & 8.000 & 12.000 \\
\hline TDS ppm & 270.80 & 59.97 & 219.00 & 254.00 & 487.00 \\
\hline D.O ppm & 9.80 & 8.20 & 6.26 & 8.15 & 70.60 \\
\hline Temp & 31.860 & 3.968 & 23.000 & 33.350 & 36.800 \\
\hline $\mathrm{Ca} \mathrm{mg/L}$ & 50.13 & 27.36 & 16.00 & 44.00 & 180.00 \\
\hline $\mathrm{Mg} \mathrm{mg} / \mathrm{L}$ & 36.25 & 45.75 & 2.00 & 24.00 & 284.00 \\
\hline $\mathrm{Cl} \mathrm{mg/L}$ & 238.9 & 331.7 & 35.0 & 142.0 & 2304.0 \\
\hline Fl mg/L & 0.4273 & 0.3999 & 0.0000 & 0.3000 & 1.7000 \\
\hline $\mathrm{Na} \mathrm{mg} / \mathrm{L}$ & 68.25 & 59.90 & 5.00 & 56.00 & 287.00 \\
\hline $\mathrm{K} \mathrm{mg} / \mathrm{L}$ & 5.925 & 5.937 & 0.000 & 4.000 & 42.000 \\
\hline
\end{tabular}

Globally, fluoride in groundwater is mostly due to geogenic in nature [27]. Some of the samples were indicated mild risk of Fluorosis as defined by WHO guidelines. Other all samples had low fluoride which can cause dental carries and other dental problems in public, however few of the samples analyzed with sufficient amount of fluoride. The areas having sufficient precipitation may involve controlling effect on excessive fluoride through dilution [28]. Dam construction is also helpful for facilitating precipitation play role in solubility of dissolved ions. The variability in the constituents of tap water relies on density of population, drainage system and industrial activities of certain region. Murad Memon which is the sub division of Malir district had noted with fluoride content ranges 0.23 to $0.19 \mathrm{ppm}$ in past study. It is highly concentrated area of low income group with agricultural activities which support Karachi. market by providing a wide range of vegetables [29]. However, current study reported fluoride from Murad Memon 0.6 to $0.9 \mathrm{ppm}$ which represented slight increase from much lower fluoride values indicates some other reasons accountable for dental illness of that area. Low level of fluoride content requires immediate consideration of local authorities to regulate fluoride. 
Table 6: Correlation Analysis

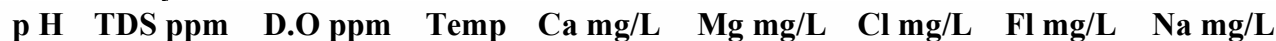

\begin{tabular}{|c|c|c|c|c|c|c|c|c|}
\hline TDS ppm & 0.294 & & & & & & & \\
\hline D.O ppm & -0.195 & 0.394 & & & & & & \\
\hline Temp & 0.172 & 0.063 & -0.183 & & & & & \\
\hline Ca ppm & 0.237 & 0.531 & -0.081 & 0.154 & & & & \\
\hline Mg ppm & -0.061 & 0.718 & 0.646 & 0.133 & 0.393 & & & \\
\hline Cl ppm & 0.070 & 0.726 & 0.263 & 0.161 & 0.693 & 0.806 & & \\
\hline Fl ppm & 0.380 & 0.536 & 0.108 & 0.214 & 0.254 & 0.292 & 0.192 & \\
\hline Na ppm & 0.202 & 0.770 & 0.346 & 0.293 & 0.573 & 0.796 & 0.845 & 0.384 \\
\hline K ppm & 0.379 & 0.621 & 0.138 & 0.257 & 0.334 & 0.390 & 0.377 & 0.441 \\
\hline
\end{tabular}

A strong correlation among $\mathrm{pH}$ and $\mathrm{F}$ is commonly observed [12], and the same was observed in this study. The $\mathrm{pH}$ may have also contributed to solubility of $\mathrm{F}$ in the groundwater. TDS is indicating parameter of salts present in water. High concentrations of dissolved solids can produce a laxative effect or may responsible for an unpleasant mineral taste. In present study it showed directly proportional relationship with fluoride. As the fluoride salts increase in water ultimately contribute to elevated TDS levels. There is also weak positive relationship observed between fluoride and ions of $\mathrm{Ca}, \mathrm{Mg}$. Leaching and ferro-magnesium minerals in land can be the source of calcium and magnesium ions. Previous studies presented direct correlation between $\mathrm{F}$ with $\mathrm{Ca}, \mathrm{Mg}$, and TDS conducted in India, and Iran [30]. Sodium and potassium also correlated moderately in current study. It was observed that there is strong correlation between $\mathrm{Na}$ and $\mathrm{Cl}$ and $\mathrm{Na}$ with $\mathrm{K}$ as these ions maintain the electrolyte balance in water. They have opposite charges so attract each other and form salts. The more divalent cations dissolved in water resulted more hardness. Calcium and Magnesium are responsible of hardness in water and they showed positive relationship with Total dissolved solids. Magnesium also showed moderate relationship with dissolved oxygen in this study.

Table 7: Principle component analysis

\begin{tabular}{lll} 
Variable & PC1 & PC2 \\
\hline p H & 0.134 & 0.539 \\
TDS ppm & 0.418 & -0.024 \\
D.O ppm & 0.184 & -0.533 \\
Temp & 0.122 & 0.350 \\
$\mathrm{Ca} \mathrm{mg/L}$ & 0.304 & 0.153 \\
$\mathrm{Mg} \mathrm{mg} / \mathrm{L}$ & 0.389 & -0.339 \\
$\mathrm{Cl} \mathrm{mg/L}$ & 0.397 & -0.148 \\
$\mathrm{Fl} \mathrm{mg/L}$ & 0.247 & 0.290 \\
$\mathrm{Na} \mathrm{mg/L}$ & 0.437 & -0.028 \\
$\mathrm{~K} \mathrm{mg} / \mathrm{L}$ & 0.325 & 0.239
\end{tabular}

Principle component analysis was executed to curtail the dimensionality of parameters. In current study the most significant principle component were PC1 and PC2 because the Eigen analysis showed values greater than one upto first two PCs. PC1 showed strong positive loadings for TDS, Ca, Mg, Cl, Fl, Na, K. There is direct link of TDS and salts content present in water. PC2 observed with dominance of dissolved oxygen, $\mathrm{pH}$ and temperature and negative relation with magnesium. Temperature and DO are inversely proportional to each other. Temperature and $\mathrm{pH}$ are also interdependent variables. As temperature increases water become acidic and $\mathrm{pH}$ decreases. 


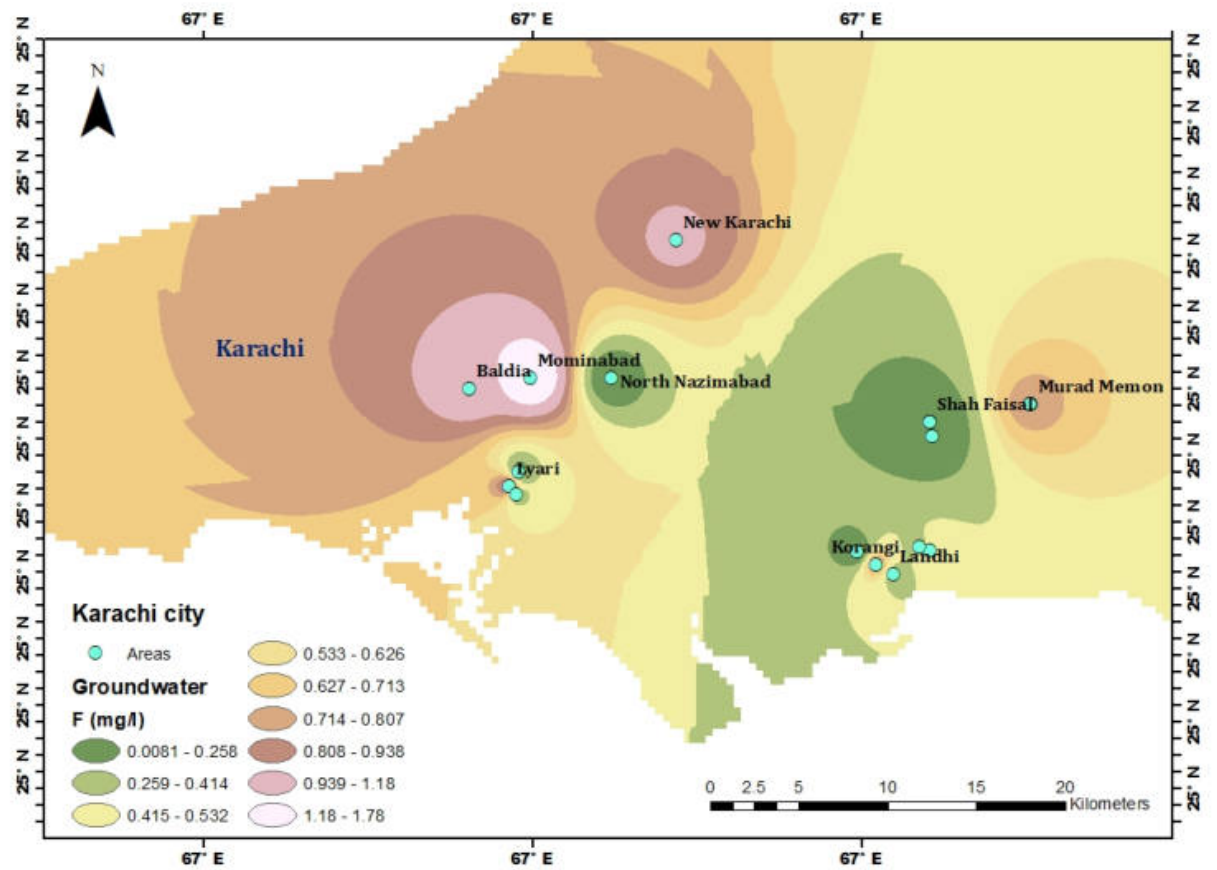

Figure 3: Contour map of spatial distribution of fluoride in ground water sample of Karachi.

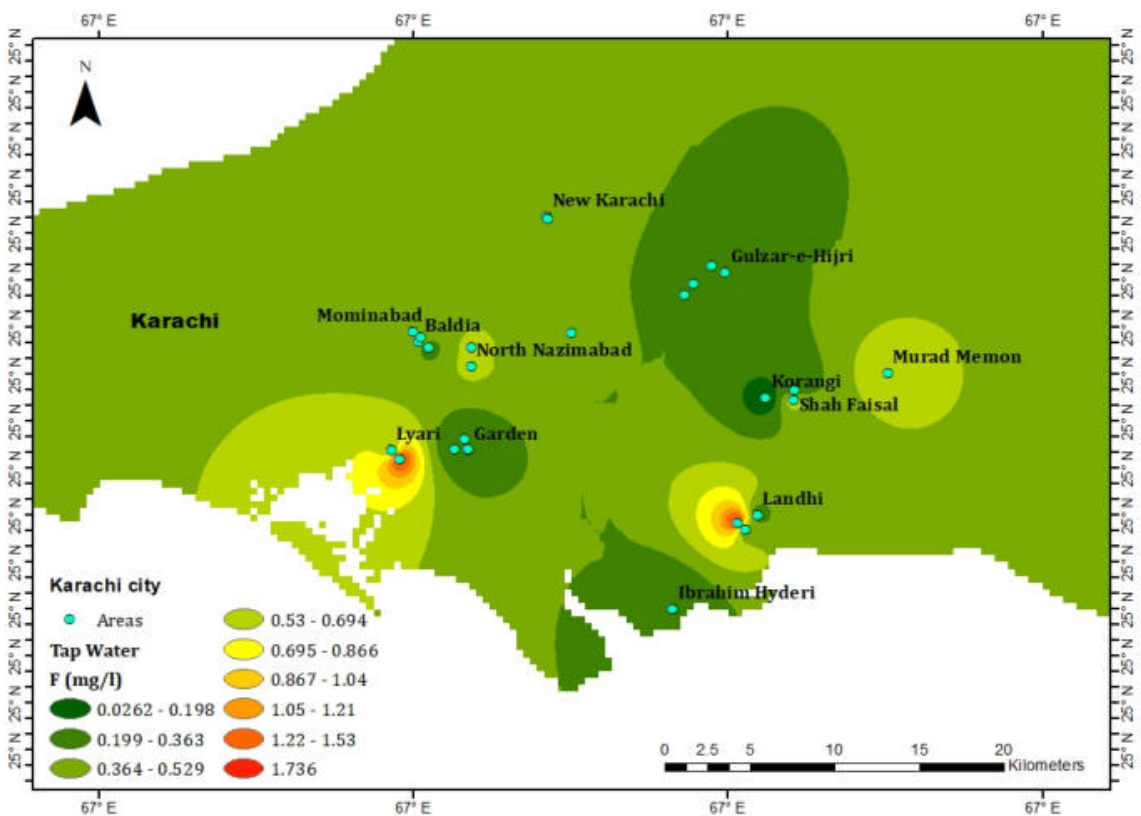

Figure 3: Contour map of spatial distribution of fluoride in tap water samples of Karachi.

\section{CONCLUSIONS}

The basic aim of present study was to analyze water quality with specific attention to presence of fluoride content in drinking water available to the residents of high density areas of Karachi. The risk analysis from medical and clinical survey revealed that population of Karachi is at risk due to the exposure of imbalance of fluoride ion in drinking water. To identify the problem behind dental illness sampling from various districts of Karachi was conducted. Few of samples showed high levels of fluoride some represented normal values within permissible 
limits of WHO while other areas highlighted with low fluoride and its related health consequences. By testing and evaluation of fluoride in drinking water being available to concentrated areas of Karachi city it was observed that public is facing the outcomes of water quality deterioration included variety of dental issues due to fluoride imbalance which should be reported and require proper management. It is suggested to control and regulate fluoride content in drinking water may solve this problem. Findings of this study will assist to contribute for the control of dental issues related to fluoride in drinking water and ensure basic health facilities in Karachi with initiative of future betterment.

\section{ACKNOWLEDGEMENT}

The authors acknowledge the efforts of Asila Ilyas provided for GIS mapping and gratitude the cooperation of public of Karachi to provide an informative medical data.

\section{REFERENCES}

1. Luby, S. E., Atiullah, N., Susan . F., Hoch , F.(2000). Limited effectiveness of home drinking water purification efforts in Karachi, Pakistan. International Journal of Infectious Diseases, 4(1), 3-7.

2. Raza, M., Hussain, F., Lee, J.Y., Shakoor, M.B., Kwon, K. D. (2017). Groundwater status in Pakistan: A review of contamination, health risks, and potential needs. Critical Reviews in Environmental Science and Technology, 47, 18.

3. Tahir, M. A., Rasheed, H. (2013). Fluoride in the drinking water of Pakistan and the possible risk of crippling Fluorosis. Journal of Drinking water Engineering and Science 6, 17-23.

4. Rasool, A ,. Farooqi, A., Xiao, T., Ali,W., Noor, S., Abiola, O., Ali, S., Nasim, W. ( 2018). A review of global outlook on fluoride contamination in groundwater with prominence on the Pakistan current situation. Environmental Geochemistry and Health, 40, 1265-1281.

5. Ausaf-ur-Rehman 1996. Groundwater as source of contamination for water supply in rapidly growing megacities of Asia: Case of Karachi, Pakistan. Journal of Water Science and Technology, 34(7-8), $285-292$.

6. Nadeem, S.M., \& Saeed, R. (2014). Determination of water quality parameters of water supply in different areas of Karachi city. Journal of European Academic Research, 1(12), 6030-6050.

7. Sorlini, S., Palazzini, D., Sieliechi, J.M., Ngassoum, M.B. (2013). Assessment of physical-chemical drinking water quality in the logone valley (chad-cameroon). Journal of Sustainability, 5, 3060-3076.

8. Ta, M. M., Derakhshani, R. B., Tavallaie, M. C., Raoof, M. D., Hasheminejad, N. E., Haghdoost, A. A. (2017). Analysis of ground water fluoride content and its association with prevalence of Fluorosis in Zarand/Kerman (Using GIS). Journal of Dental Biomaterials, 4(2).

9. Ayoob, S. \& Gupta, A. K. (2006). Fluoride in drinking water: a review on the status and stress effects. Critical Reviews in Environmental Science and Technology, 36, 4.

10. Suthar, S., Vinod, K., Garg, Jangir, S., Kaur, S., Goswami, N., Singh, S. (2007). Fluoride contamination in drinking water in rural habitations of Northern Rajasthan, India. Journal of Environmental Monitoring and Assessment, 145, 1-6.

11. Amanlou, M., Hosseinpour, M., Azizian, H,. Khoshayand, M.R., Navabpoor, M., Souri, E. (2010). Determination of fluoride in the bottled drinking waters in Iran. Iranian Journal of Pharmaceutical Research, 9(1), 37-42.

12. Hanse, A., Chabukdhara, M., Baruah, S. G., Boruah, H., Gupta, S. K. (2019). Fluoride contamination in groundwater and associated health risks in Karbi Anglong District, Assam, Northeast India. Journal of Environmental Monitoring and Assessment, 191(12).

13. Peckham, S. \& Awofeso, N. (2014). Water Fluoridation: A critical review of the physiological effects of ingested fluoride as a public health intervention. Journal of Scientific World, 10.

14. Ocak, E., Van, S. K., (2018). Determination of fluoide in water, milk and dairy products. Research report Fluoride, 51(2), 182-192.

15. Isaac, S., Brudevold, F., Smith, F.A., Gardner, D. E. (1958). The relation of fluoride in drinking water to the distribution of fluoride in enamel. Journal of Dental Research, 37(2).

16. Bassin, E. B., Wypij, D., Davis, R. B., Mittleman, M. A. (2005). Age-specific fluoride exposure in drinking water and Osteosarcoma (United States). Journal of Cancer Causes Control, 17, 421-428.

17. Wang, X. S., Wang, Z. H., Cheng, X. T., Li, J., Sang, Z. P., Xiang-Dhong Zang, Ling-Ling Han, Xiao-Yang Qiao, Zhao-Ming Wu, Zhi Quan Wang. (2007). Arsenic and Fluoride Exposure in Drinking Water: Children's IQ and Growth in Shanyin County, Shanxi Province, China. Journal of Environmental Health Perspective 115(4), 643-647.

18. Dobaradaran, S., Mahvi, S. H., Dehdashti, S., Abadi, D. R. V. Tehran, Iran (2008). Fluoride content in bottled drinking water available in Iran. Research Note Fluoride, 41(1), 93-94.

19. Adejumoke, A., Babatunde, O. (2018). Water pollution: Effects, Prevention and Climatic Impact. Open access book Intech open. Chapter 3 1-23. 
20. Khan, M.K., Ayoub, W., Saied, S., Hussain, M.M., Masood, S. S., Siddique, A., Khawaja, H.A. (2019). Statistical and Geospatial Assessment of Groundwater Quality in the Megacity of Karachi. Journal of Water Resource and Protection, 11(3) 22.

22. Mehmood. K., Alamgir, A., Khan, M.A. (2014). Seasonal variation in water quality of lower Sindh, Pakistan. FAUSST Journal of Biology, 4(2), 147-156.

23. Panjwani, S. K., Ronkanen, A. K., Khan, A.B. (2018). Drinking water quality and environmental monitoring in rural areas of district Malir, Karachi. Journal of Environmental Engineering, 61.

24. Adimalla, N., Venkatayogi, S. (2018). Geochemical characterization and evaluation of groundwater suitability for domestic and agricultural utility in semi-arid region of Basara, Telangana state, South India. Journal of Applied Water Science, 8(44).

25. Banerjee, A. (2015). Groundwater fluoride contamination: A reappraisal Geoscience Frontiers, 6 (2), 277 284.

26. Malana, M.A. Khosa, M. (2010). Groundwater pollution with special focus on arsenic, Dera Ghazi KhanPakistan. Journal of Saudi Chemical Society, 15, 39-47.

27. Frazão , P., Peres, M.A., Cury, J.A. (2011). Drinking water quality and fluoride concentration. Revista de Saúde Pública, $45,4$.

28. Kimambo, V., Bhattacharya, P., Mtalo, F., Mtamba, J., Ahmad, A. (2019). Fluoride occurrence in ground water systems at global scale status of defluoridation- Stat of the art. Ground water for Sustainable Development 9.

29. Siddiqui, A., Mumtaz, M., Saied, S., Karim, Z., Zaighum, N.A. (2006). Fluoride Concentration in Drinking water of Karachi City (Pakistan). Journal of Environmental Monitoring and Assessment, 120, 177-185.

30. Rahmani, A., Rahmani, K., Dobaradaran, S., Mahvi, A. H., Mohamadjani, R., Rahmani, H. (2010). Child dental carries in relation to fluoride and some inorganic constituents in drinking water in Arsanjan, Iran. Research Report Fluoride, 43(3), 179-186.

31. Raza, M., Hussain, F., Lee, J. Y., Shakoor, M. B., Kwon, K. D. (2017).Groundwater status in Pakistan: A review of contamination, health risks, and potential needs. Critical Reviews in Environmental Science and Technology, 47, 18.

32. Tahir M.A. and Rasheed. H. (2013). Fluoride in the drinking water of Pakistan and the possible risk of crippling Fluorosis. Journal of Drinking water Engineering and Science, 6, 17-23.

33. Rasool, A., Farooqi, A ,. Xiao, T., Ali, W., Noor, S., Abiola, O., Ali, S., Nasim, W., 2018. A review of global outlook on fluoride contamination in groundwater with prominence on the Pakistan current situation. Journal of Environmental Geochemistry and Health, 40, 1265-1281.

34. Ausaf-ur-Rehman 1996. Groundwater as source of contamination for water supply in rapidly growing megacities of Asia: Case of Karachi, Pakistan. Journal of Water Science and Technology, 34(7-8), $285-292$.

35. Saqib, S. M. \& Saeed. R. (2014). Determination of Water Quality Parameters of Water Supply in Different Areas of Karachi City. Journal of European Academic Research, 1(12), 6030-6050.

36. Ayoob, S., Gupta, A. K. (2006). Fluoride in drinking water: a review on the status and stress effects. Critical Reviews in Environmental Science and Technology, 36, 433-487.

37. Suthar, S., Vinod, K., Garg, Jangir, S., Kaur, S., Goswami, N., Singh, S. (2007). Fluoride contamination in drinking water in rural habitations of Northern Rajasthan, India. Journal of Environmental Monitoring and Assessment, 145, 1-6. 